\title{
Planning, Organizing and Management of the Collaborative Project on Breast Cancer
}

\author{
Santoso Cornain ${ }^{*}$
}

\begin{abstract}
Abstrak
Kanker payudara tetap merupakan masalah penting baik di negara maju maupun di negara yang sedang berkembang, yang memerlukan penelitian lebih lanjut dalam beberapa aspek. Suatu penelitian kerjasama tentang etiologi dan klinikopatologi kanker payudara antara Jepang dan Indonesia telah dilaksanakan. Perencanaan, pengorganisasian dan manajemen dari proyek kerjasama tersebut dikembangkan di bawah koordinasi baik tim. Jepang maupun tim Indonesia. Baik tujuan umum dan tujuan khusus dan hipotesis yang sesuai ditetapkan dan dirumuskan berdasarkan tiga aspek penelitian, termasuk penelitian epidemiologik, klinik dan palobiologik. Proyek tersebut telah dirancang dalam fase-fase yang dimulai dengan penelitian pendahuluan ('pilot study') dan diikuti dengan penelitian definitif. Pembahasan meliputi 5 fase manajemen proyek, yaitu 2 fase perencanaan (penetapan dan perencanaan) dan 3 fase implementasi (pengorganisasian, manajemen / pengelolaan dan pengakhiran), yang dimodifikasi sesuai dengan proyek penelitian khusus. Di antara berbagai upaya yang sesuai maka pembinaan tim dengan kepemimpinan telah menjadi sangat penting untuk diperhatikan, karena beberapa hal yang dihadapi i.e. kelompok profesional dan ilmiah, tim mulidisipliner dan proyek penelitian internasional.
\end{abstract}

\begin{abstract}
s
Breast cancer remains as an important problem in both developed and developing countries, which needs further investigations in several aspects. A collaborative studies on the etiology and clinicopatholoy of breast cancer between Japan and Indonesia has been carried out. The planning, organizing and management of the collaborative project were worked out under the coordination of both the Japanese and the Indonesian teams. Both general and specific objectives and corresponding hypotheses were defined and formulated in respect to a threefold studies including epidemiological, clinical and pathobiological studies The project has been designed in phases initiated by pilot study and followed by definitive study. The description covers 5 phases of project management, namely 2 phases of planning (definition and planning) and 3 phases of implementation (organizing, management / controlling and terminating) with some modification as to adjust to specific research project. Among related attempts team building and leadership have become very important which needed special attention, due to several respects to deal with i.e. professional and scientific group, multidisciplinary team and international research project.
\end{abstract}

Keywords: collaborative project, planning, organization, management, implementation, breast cancer, team, Indonesia-Japan.

- Department of Anatomic Pathology and Research Center for Medical Science and Technology, Faculty of Medicine, University of Indonesia, Salemba 6, Jakarta 10430, Indonesia.

Coordinator of the Indonesian team, Japan-Indonesia Joint Study on Etiology and Clinicopathology of Breast Cancer.
Breast cancer remains as an important cancer problem, both in the developed countries, such as Japan and in the developing ones, such as Indonesia. The data collected from 13 Pathology Laboratories spread throughout Indonesia by the National Center for Pathology based Cancer Registry showed that breast cancer ranked the second among females, $18.03 \%$ relative frequency (ASCAR= aged standardized cancer ratio $17.84 \%$ ) in 1988 and $18.44 \%$ (ASCAR 17.46 $\%$ ) in 1989. 1,2 Similar findings were also revealed in two Population based Cancer Registries at two provinces: Yogyakarta and Semarang.

In spite of the difficulty to achieve ideal population based registry such data has been appreciated as repre- 
senting the similar situation in the geographical area and ethnical group, i.e. Asia and Afrika. ${ }^{4}$ Furthermore, the estimates could be used to generate hypotheses of etiological factors.

The annual incidence of breast cancer in Japan has been reported to be lower, i.e. 12.1-16.6 per 100.000 females, than in America, i.e. 71.7 per 100.000 females, as indicated in the Cancer Incidence in Five Continents, published by the International Agency on Research on Cancer. ${ }^{5}$ Increased figures have been estimated and reported in later studies ${ }^{6-8}$, namely up to 21 per 100.000 females in Japan and up to 91 per 100.000 in Northern America.

Such difference has attracted several investigators to look upon several aspects of breast cancer, including the epidemiological, clinical and pathological studies, by paying attention to the biological behaviour of the disease as well as the early breast cancer issues.

An International collaborative Study on Breast cancer has been proposed in order to allow comparative studies looking on both the Indonesian patients and the Japanese ones, in respect to both the similarities and dissimilarities. A multidisciplinary groups/teams were established, including the epidemiologists, breast cancer surgeons and pathologists/immunopathologists from both sides. The Aichi Cancer Center, Nagoya City University, Nagoya University, Nagoya and the Cancer Institute (Gann Ken), Tokyo, Japan have been collaboratineg with the Faculty of Medicine, University of Indonesia, Jakarta.

The study has been initiated by the support of a three year grant No. 01042007 (April 1, 1989-March 31, 1992) under the auspices of the Ministry of Education, Science and Culture, the Government of Japan and the authorization by the Dean, Faculty of Medicine, University of Indonesia, No. 4383/PT02.H4.FK/E/88.

Favorable situation was given by the fact that the issues of breast cancer were consistent with two among the priorities of the programmes of the Faculty of Medicine, University of Indonesia, namely the fields of Oncology \& Degenerative Disease and the Human Reproductive Health.

The preliminary study has revealed that fatty consumption was found among other significant risk factors. Both teams were interested to study further about the nutritional factors, relative to the Indonesian situation. The nutritionists, both from the University of Indonesia and the Research and Development Center for Nutrition of the Ministry of Health, were considered to be added to the working teams.
Corresponding to the progress and the findings a two year extension grant was provided, i.e. No. 04042013 (April 1,1992-March 31, 1994).

The present paper will describe the planning, organizing and management of the international collaborative study. The description will cover 5 phases of project management, ${ }^{9}$ namely 2 phases of planning (defining and planning) and 3 phases of implementation (organizing, management/controlling and terminating) with some modifications as to adjust to similar guidance $^{10,11}$ and to fit to specific research project. ${ }^{12,13}$

\section{Planning the collaborative study}

\section{Further situation analysis}

During the early Consultation Meetings the definitive planning of the collaborative study, a research project with three fold study namely the epidemiological aspects, clinical aspects and histopathological aspects of breast cancer, was put forward. In addition to the informations about the breast cancer problems both in Indonesia and in Japan mentioned above, the situation analysis has revealed that the materials, namely the number cases and controls, could be expected to be collected in Dr. Cipto Mangunkusumo National Central General Hospital, Jakarta in sufficient number i.e. 75 to 100 per annum. Since this is the biggest state general hospital, the majority of the patients visiting the hospital were expected to consist of low to middle socioeconomical class people.

As counterpart, the Cancer Institute, Tokyo had the highest number of breast cancer patients in Japan. High level laboratory and clinical expertise were also available in both places. Strong epidemiological groups of both sides also support substantially the theme of the joint study emphasizing on the epidemiological study.

\section{Establishment of strategies and collaborating teams}

The collaborating teams were established, namely the Japanese team which will work with their counterparts the Indonesian team. The coordinator of the Japanese team was Dr. Yoshiyuki Ohno, Epidemiologist, Chairman of the Department of Preventive Medicine, formerly at Nagoya City University and later at Nagoya University, Nagoya; while the members were Dr. Nakako Kubo, Epidemiologist, Department of Preventive Medicine, Nagoya City University, Nagoya, Dr. Goi Sakamoto, Pathologist, Chief, Department of Pathology, Cancer Institute, Tokyo, Dr. 
Susumu Watanabe, Surgeon, Department of Surgery, Cancer Institute, Tokyo. During later phase, Dr. Nakako Kubo was replaced by Dr. Kenji Wakai and Dr. Sadao Suzuki, Epidemiologists, Department of Preventive Medicine, Nagoya University. The coordinator of the Indonesian team was Dr. Santoso Cornain, Immunopathologist, Department of Anatomic Pathology, Faculty of Medicine, University of Indonesia, Jakarta; while the members were Dr. Joedo Prihartono and Dr. Setyawati Budiningsih, Epidemiologists, Department of Community Medicine, Faculty of Medicine, University of Indonesia, Jakarta, Drs. Didid Tjindarbumi, Muchlis Ramli and Idral Darwis, Surgeons, Department of Surgery, Faculty of Medicine, University of Indonesia, Jakarta, Drs. Gunawan Tjahjadi, Esti Sutrisno and Endang Sri Roostini, Pathologists, Faculty of Medicine, University of Indonesia, Jakarta.

The coordinators were supposed to function as the leaders of the multidisciplinary teams and attempted to obtain full support from their heads of the departments to work toward the relevant goals.

Supervisory support has been provided by the Dean of the Faculty of Medicine, University of Indonesia. Corresponding support has been also obtained from the Director of Dr. Cipto Mangunkusumo Hospital and Director of Research and Development Center for Nutrition, Ministry of Health.

The linker system within the team was also established in order to encourage direct communication as required during the study.

In each study field, the team was supported by corresponding working group including interviewers, nurses, nutritionists and laboratory technicians.

Among related attempts team building and leadership $^{9-11}$ have become very important which needed special attention, due to several respects to deal with i.e. professional and scientific group, multidisciplinary team and international research project.

\section{Designing and writing research proposal}

Further planning has been discussed in both the joint meeting between the Indonesian and Japanese teams in the Consultation Meeting and in the local team meetings.

The purpose and objective of the study has been further defined and written in the official proposal for grant application. Thus, the three folds study including epidemiological, clinicopathological and nutritional aspects of breast cancer have been clarified with general and specific objectives for each field.

The collaborative research was designed in phases, initiated with pilot study followed by definitive study.

The epidemiological study on risk factors in breast cancer was planned as case-control study. ${ }^{13}$ Eligibility of cases and controls were determined in the methodology (given in the accompanying paper). A preliminary qestionnaires and its guidelines for interviewers were developed and tested in the pilot study. The questionnaire were then standardized after some modification for further data collection in the definitive study. The standardized questionnaire were printed with copies using non-carbonized papers for direct data distribution to both Japanese and Indonesian teams. See Appendix-A. They were made in English and in Indonesian languange. The English version was sent to Japan, while the Indonesian version was meant for comprehensive use by the nurses for interviewing the Indonesian breast cancer patients and controls. The manual for interviewer was given. See Appendix- $B$.

The clinical study was planned for analyzing clinical aspects of the disease and special clinical study form was developed for data collection. See Appendix-C.

The histopathological study was planned for analyzing histopathological features of breast cancers. Similar studies were conducted in Japan, applying basic design of case-control study.

In the extension study further nutritional analysis was planned by developing special questionnaire. This was also tested in a pilot study before starting the definitive study of nutritional analysis. For the extention study the questionnaire for epidemiolgoical study were simplified to accompany the questionnaire for nutritional study. See Appendix-D and Appendix-E.

\section{Implementation of research project.}

The implementation includes organizing, controlling and terminating the project.

\section{Organizing the project.}

After approval of the proposal the components of the research project were communicated to the team members and related supervisors in order to allow sufficient preparation for implementing the project. The teams were provided with the available informations on breast cancer in Japanese women. ${ }^{14,15}$

It was considered important to standardize the identification and diagnosis of the breast cancer cases. 
Therefore, the Indonesian pathologist was sent to the Cancer Institute, Tokyo, to allow common agreement in the histopathological identification of breast cancer cases. The general rules for clinical and pathological recording of breast cancer ${ }^{16}$ were thoroughly discussed with direct clinicopathological presentations.

For the clinical study in Indonesia it was agreed to apply the management protocol of the Indonesian Surgical Oncology Association ${ }^{17}$ which was adapted from widely accepted standards.

The activities of the teams were coordinated and organized specifically. The epidemiologists supervized the collection of epidemiological data by interviewing cases and matched controls, by well trained interviewers using standardized questionnaires.

The identification and diagnosis of breast cancer cases were performed by the clinicians (breast surgeons), which also evaluated related clinicopathological data. The pathologists were responsible for evaluating the histopathological features of specimens derived from breast cancer cases. Modified WHO histopathological classification recommended by Japanese Society for Breast Cancer was used.

In addition, the interest was given to include the study of the expression of hormonal (estrogen and progesteron) receptors, since the team considered it might be applicable to the present study ${ }^{18,19}$ and for clinical management. The immunopathologist was responsible to take care of establishing the related immunoperoxidase techniques.

The study has been inwater with pilot study in two phases, carried out in December 1988 and January 1989. It was followed by definitive study in three phases carried out until November 1991.

Since the preliminary results ${ }^{20}$ indicated interesting findings, inter alia that fatty food consumption was shown as significant risk factor in the Indonesian breast cancer as well, an extension study on further nutritional analysis has been granted.

In the extension study nutritionists organized preliminary study for further nutritional analysis. The teams started to study the guideline provided by the Japanese experience. ${ }^{21,22}$ They are responsible for supervizing the nutritional data collection by interviews conducted by well-trained field nutritionists using special nutritional questionaire.
Further data processing and analysis were performed by electronic data processing, using computer softwares i.e. standard statistical packages (SPSS and SAS) and Food Composition Tables.

\section{Management and controling of the project.}

Further arrangements were made in relation to the scheduling and assignment of the tasks, according to Gannt Chart system and Work Breakdown Structure or Flow Chart. See Fig. 1 \& 2. Control system was developed for ensuring the completeness and reliability of data collection, regular communications among the team members and immediate evaluations of the progress of the study. Materials of progress reports were being made by each study field team and collected by the coordinator. Informal and formal team meetings were carried out periodically. Regular Consultation Meetings between Japanese and Indonesian teams were scheduled 3 times per year, to discuss the grant, progress of the research, data analysis and report writing. Progress reports were made ready after summing up of each Consultation Meeting.

Thus, diversity could be managed and controversy could be made constructive. Close communicating were also established by express mail service, telefax, electronic mail or direct phone call. The above mentioned model had tremendous power to instill project leadership and to implement team development to achieve high performance team. ${ }^{23,24}$ The latter helped implementation of total quality control. ${ }^{25,26}$

In the mean time, rearrangement and reorganizing of the activities and methodologies were made in respect to solving problems, such as the irregular procurement of cases and controls due to temporary change of hospital ward situation and data analysis toward micronutrient due to unavailable Food Composition Table for certain food items.

The budgetting was arranged according to 'per unit cost system' relative to number of subjects (cases plus controls), which covered costs for activities mentioned above plus overhead costs.

Part of the budget was specially allocated for paper writing and its publication in standard international journals as well.

Besides the grant provided by the Ministry of Education and Culture, the Government of Japan, part of the funding was supported by the grant from the Indonesian Cancer Foundation. 
Figure 1

Gant Chart of Schedules of Activities: (part of second batch study)

Activity

Time

Nov 91

Dec 91

Jan 92

Feb 92

Mar 92

12

$123 \quad 3$

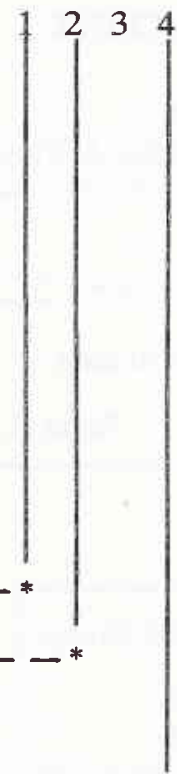

1234

$\begin{array}{llll}1 & 2 & 3 & 4\end{array}$

1. Revision of questionnaire draft $-----\cdots *$

- Form $A=$ Epidemiological

- Form B=Nutritional

2. Finalization of questionnaires $--\cdots+--*$

3. Training of interviewers: Epi- $--\ldots----^{*}-*$ demiological and Nutritional questionnaire respectively

4. Meeting on the system $--------\cdots---^{*}$

5. Revision of questionnaire forms $--------\cdots$ and system : Multiplication of forms

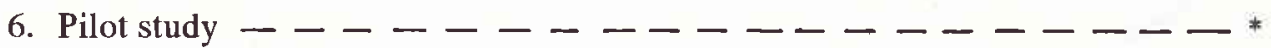

7. 12th Consultation Meeting $-\ldots-\ldots-----------^{*}$

8. Definitive study $-------------------1-----_{-}^{*}$

9. Progress report writing $------------------_{-}^{*}$

Thus, by the end of the third year the collection of data could be completed to 300 cases and 600 controls for the first batch of the study. This has fulfilled the original planning i.e. estimated 75 cases per year.

The attempts to perform biochemical analysis for triglycerides, cholesterol, beta-carotene and retinol in sub-samples of breast cancer patients were not yet successfully done due to shipment trouble to Japan. The duplicates of the samples are going to be tested in Jakarta and incorporated to the post-project planning. Such study has been considered important to clarify the micronutrients related to the risk of breast cancer. ${ }^{27}$

In the mean time, preliminary/pilot study of the nutritional analysis has been performed. The results have been used to design the definitive study of nutritional analysis.

Final reports, including pilot study of the nutritional analysis, have been made and the results have been discussed in a One Day Seminar. The full papers are being published in this issue of the journal.

Definitive study of the nutritional analysis (second batch of the study) is in progress. Further analysis in epidemiological, clinicopathological and nutritional aspects are being prepared for further publications.

As for post-project planning, the teams are interested to extend further studies including: 1) Further analytical phase of the epidemiological study of risk factors, 2) Further clinicopathological study in early breast cancer and breast conserving treatment, and 3) Further pathobiological study i.e. the roles and interaction of hormonal (estrogen and progesteron) receptors and the oncogenes (c-erbB-2 and p53). The evaluation of such molecular markers still needs clarifying for the relationship of their expressions to the breast cancer risk, prognosis and response to treatment. ${ }^{18,28,29}$ 


\section{Figure 2}

\section{Case-Control Study: Nutritional Analysis on Breast Cancer}

Flow Chart of Data Collection of Cases and Controls:

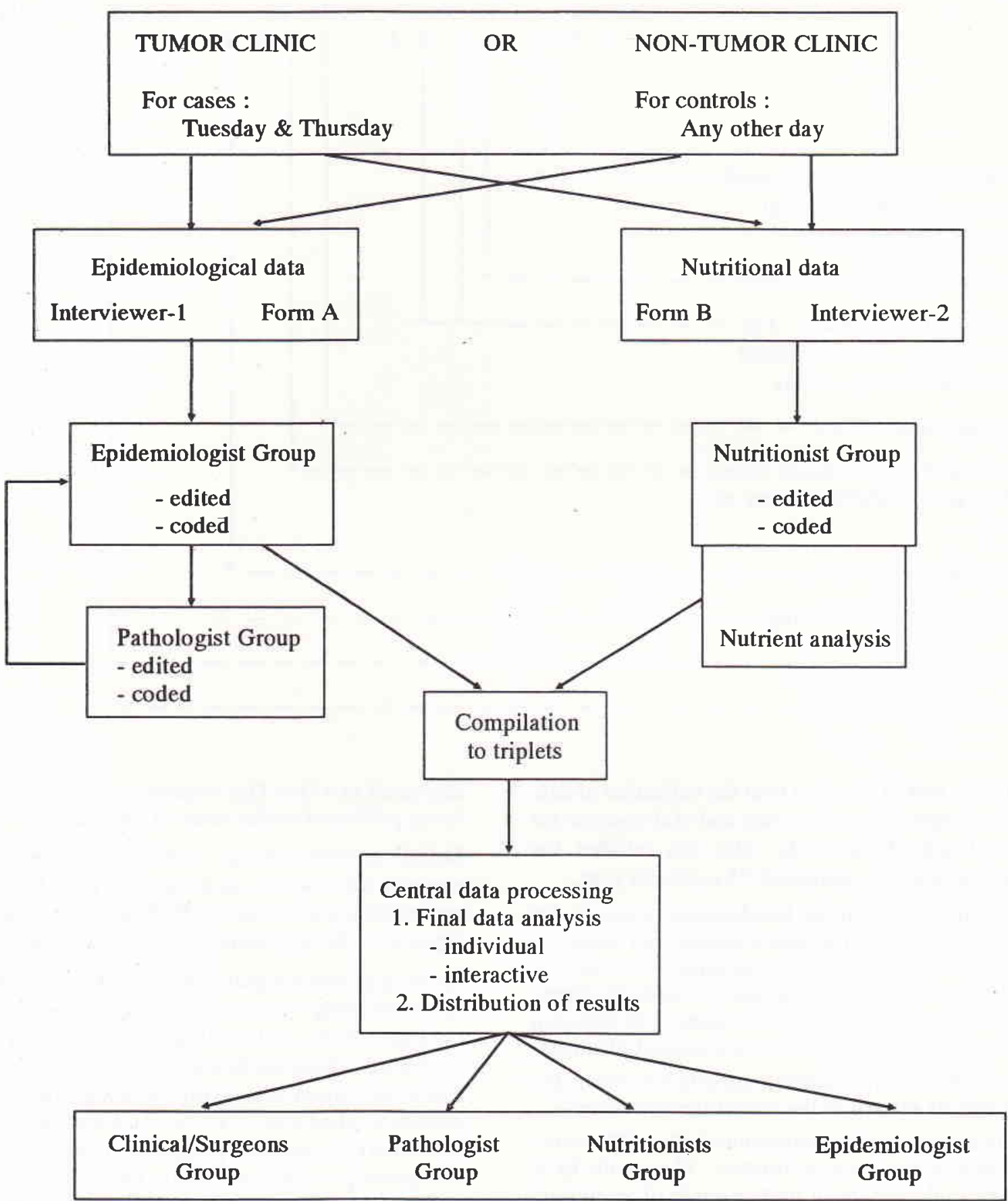




\section{Terminating the project}

The overall picture of the progress of collection of cases and controls is given in Table 1.

Table 1. The progress of the project:

\begin{tabular}{llcc}
\hline \multicolumn{2}{l}{ a. Main study/first batch study } & & \\
Phase & Period & \# cases & \# controls \\
\hline Pilot Study : & & & \\
\hline Pilot-1 & Dec 1988 & 20 & 40 \\
Pilot-2 & Jan 1989 & 22 & 44 \\
\hline Definitive Study: & & & \\
\hline Phase-1.1. & May 1989 & 57 & 44 \\
Phase-1.2. & Feb 1990 & 45 & 118 \\
\hline Phase-2.1. & Jun 1990 & 30 & 48 \\
Phase-2.2. & Oct 1990 & 53 & 73 \\
Phase-2.3. & Feb 1991 & 28 & 57 \\
\hline Phase-3.1. & May 1991 & 11 & 22 \\
Phase-3.2. & Nov 1991 & 34 & 138 \\
\hline & Sub total & 300 & 600 Total = 900
\end{tabular}

Detailed analysis bas been able to perform after complete data management covering 300 triplets data sets.

b. Extension study/second batch study

\begin{tabular}{|c|c|c|c|c|}
\hline Phase & Period & \# cases & \multicolumn{2}{|l|}{ \# controls } \\
\hline \multicolumn{5}{|l|}{ Pilot Study } \\
\hline \multirow[t]{2}{*}{ Pilot-1 } & Feb 1992 & $5 \mathrm{~A}$ & - & \\
\hline & & $5 \mathrm{~B}$ & - & \\
\hline Pilot-2 & May 1992 & $20 \mathrm{~A}$ & $40 \mathrm{~A}$ & \\
\hline \multirow{2}{*}{\multicolumn{2}{|c|}{ Definitive Study : }} & & & \\
\hline & & $\#$ cases \# & $\#$ control-1 & \# control-2 \\
\hline \multirow[t]{2}{*}{ Phase 1.1.} & Sept 1992 & $28 \mathrm{~A}(4)$ & $8 \mathrm{~A}$ & $3 \mathrm{~A}(2)$ \\
\hline & & $15 \mathrm{~B}(4)$ & $8 \mathrm{~B}$ & $3 \mathrm{~B}(2)$ \\
\hline \multirow[t]{2}{*}{ Phase 1.2. } & Febr 1993 & $16 \mathrm{~A}(7)$ & $16 \mathrm{~A}$ & $6 \mathrm{~A}(4)$ \\
\hline & & $29 \mathrm{~B}(7)$ & $16 \mathrm{~B}$ & $6 \mathrm{~B}(4)$ \\
\hline
\end{tabular}

Notes: $\mathrm{A}=$ subjects interviewed for epidemiological data (Form A2)

$\mathrm{B}$ = subjects interviewed for nutritional data (Form B2)

()$=$ subjects sampled for blood tests

\section{Acknowledgments}

The author is grateful to Prof. Haruo Sugano, Cancer Institute Hospital, Tokyo, Profs. Kunio Aoki and Suketami Tominaga, Aichi Cancer Center, Nagoya and Prof. Yoshiyuki Ohno, Nagoya University, Nagoya and the Dean, Faculty of Medicine, University of Indonesia, Jakarta for the arrangements and the authorization of the collaborative project. The author is also indebted to the Director of Dr. Cipto Mangunkusumo National Central General Hospital and the Heads of the Departments of Surgery, Community Medicine, Anatomic Pathology, Nutrition, Faculty of Medicine, University of Indonesia and the Director of Research and Development Center for Nutrition, Ministry of Health, Bogor for allowing excellent multidisciplinary team building and implementation of the project.

This work was supported by the Ministry of Education and Culture, Japan, Grants No. 01042007 and 04042013 ; and was partly supported by the Indonesian Cancer Foundation. This collaborative study was a part of Special Cancer Research Project in Monbusho International Scientific Research Program, with the approval of the Dean, Faculty of Medicine, University of Indonesia, No. 4383 / PT02.H4.FK / E / 88.

\section{REFERENCES}

1. Cornain S, Mangunkusumo R, Nasar IM, Prihartono J. Ten Most Frequent Cancers in Indonesia: Pathology based Cancer Registry Data of 1988-1989. In: Cancer Registry in Indonesia. National Cancer Registry Center, Jakarta Coordinating Board, 1990.

2. Prihartono J, Mangunkusumo R, Partoatmodjo P. Establishing pathology based cancer registry: Indonesian experience. In: Sasaki R, Aoki K, editors. Epidemiology and Prevention of Cancer. Proceedings of Monbusho (Ministry of Education, Science \& Culture) International Symposium on Comparative Study of Etiology \& Prevention of Cancer, Nagoya, 1989. Nagoya: The University of Nagoya Press, 1990: 211-6.

3. Sarjadi. Cancer Incidence 1985-1989 in Semarang, Indonesia. Indonesian Cancer Society, 1990.

4. Parkin DM. The nature and sources of cancer data from developing countries. In: Khogali M, Omar YT, Gjorgov A, Ismail AS, editors. Cancer prevention in developing countries. Proceedings of the 2 nd UICC Conference on Cancer Prevention, Kuwait, 1986. Oxford: Pergamon Press, 1986:9-22.

5. WHO and IARC. Cancer Incidences in Five Continents. IARC Sci Publ No.15, Vol.III, Lyon, 1976.

6. Parkin DM, Laara E, Muir CS. Estimates of the worldwide frequency of sixteen major cancers in 1980 . In $\mathrm{J}$ Cancer 1988;41:184-97. 
7. Donn AS, Muir CS. Breast cancer: Epidemiology and risk factors. In: Khogali M, Omar YT, Gjorgov A, Ismail AS, editors. Cancer prevention in developing countries. Proceedings of the 2nd UICC Conference on Cancer Prevention, Kuwait, 1986. Oxford: Pergamon Press, 1986:155-66.

8. Hanai A, Fujimoto I. Population-based cancer registry in Japan. In: Sasaki R, Aoki K, editors. Epidemiology and Prevention of Cancer. Proceedings of Monbusho (Ministry of Education, Science \& Culture) International Symposium on Comparative Study of Etiology \& Prevention of Cancer, Nagoya, 1989. Nagoya: The University of Nagoya Press, 1990:199-210.

9. Weiss JW, Wysocki RK. 5-phase project management: A practical planning and implementation guide. Massachusetts: Addison-Wesley Publishing Co., 1992.

10. Michael N, Burton C. Basic project management. Singa pore: Singapore Institute of Management and Heinemann Asia, 1992.

11. Dyer WG. Team Building: Current Issues and New Alternatives. 3rd ed. New York: Addison-Wesley Publishing Co. 1995.

12. Hawkins C, Sorgi M. Research: How to Plan, Speak and Write about it. Singapore: Narosa Publishing House, Toppan Company (S) Pte. Ltd., 1992.

13. Boyd NF. Epidemiology of cancer. In: Tannock IF, Hill RP, editors. The basic Science of Oncology. 2nd ed. New York: McGraw- Hill Inc., 1992:7-22.

14. Sakamoto G, Sugano H, Hartman WH. Comparative Pathological study of breast carcinoma among American and Japanese women. In: McGuire WL, editors. Breast Cancer. Nashville USA: Plenum Publishing Co., 1981.

15. Sakamoto G, Sugano H. Pathology of breast cancer: Present and prospect in Japan. Breast Cancer Research and Treatment 1991;18:S81-3.

16. Japanese Breast Cancer Society. The general rules for clinical and pathological recording of breast Cancer. Jpn J Surgery 1989;19:612-32.

17. Indonesian Surgical Oncology Association. Breast Cancer - Management Protocol. (In Indonesian). Ropanasuri 1989; 18:89-93.

18. McTieman A, Thomas DB, Johnson LK, Roseman D. Risk factors for estrogen receptor-rich and estrogen reseptor-poor breast cancers. JNCI 1986;77:849-54.
19. Cavalli PF. Clinical research in advanced breast cancer: Back to the future? Ann Oncology 1991;2:621-2.

20. Cornain S, Ohno Y. Progress Report: Japan-Indonesia Joint Study on Etiology and Clinico pathology of Breast Cancer, Jakarta: School of Medicine University of Indonesia, 1992, May.

21. Ohno Y. Methodology and evaluation of dietary factors in Japan. In: Mettline CJ, Aoki K, editors. Recent Progress in Research on Nutrition and Cancer. New York: Wiley-Liss Inc., 1990:11-20.

22. Ohno Y, Yoshida O, Oishi K, Okada, Yamate H, Schoeder FH. Dietary B-carosene and cancer of the produk: A casecontrol study in Kyoto, Japan. Cancer Res 1988; 48:1331-6.

23. Breiner W, Geddes M, Hastings C. Project leadership. Hampshire: Gower Publishing Co.Ltd., 1993.

24. Katzenbach JR, Smith DK. The Wisdom of Teams: Creating the high Performance Organization. Boston: Harvard Business School Press, 1993.

25. Besterfield DH. Quality control. $3^{\text {rd }}$ ed. New Jersey: Prentice-Hall Inc., 1990.

26. Ichikawa $\mathrm{K}$. What is total quality control ? The Japanese way. (LuDJ, translator). New Jersey: Prentice-Hall Inc, 1985.

27. Potischman N, McCulloch CE, Byers T, Houghton L, Nemoto T, Graham $S$ et al. Associations between breast cancer , plasma triglycerides and cholesterol. Nutr Cancer 1991;15:205-15.

28. Iwaya K, Tsuda H, Hiraide H, Tamaki K, Tmakuma S, Fukutomi $\mathrm{T}$ et al. Nuclear p53 immunoreaction associated with poor prognosis of breast cancer. Jpn J Cancer Res $1991 ; 82: 835-40$.

29. Takikawa $Y$, Noguchi $M$, Kitagawa $H$, Thomas $M$. Immunohistochemical detection of $\mathrm{p} 53$ and c-erbB-2 proteins: Prognostic significance in operable breast cancer. Breast cancer 1994;1:17: 23. 